\title{
Potential for Performance-Based Regulation in the CANADIAN OFFSHORE OIL AND GAS INDUSTRY
}

\author{
Rob Grant, Q.C., Will MOREIRA, Q.C. \\ AND DAVID HENLEY
}

Affer providing a background and comparative assessment of Performance-Bused Regulation (PBR) in other offshore oil and gas sectors, the potential for similar application in Canada is discussed. The developments in these sectors have evolved from a prescriptive regulaton' scheme to one that is more $P B R$ based. In such a regime, the governing agency sets out objectives for industry performance that include design and operation objectives, as well as expectations for safen and environmental protection. It is then up to the individual company to develop a program as to how they propose to achieve these performance objectives, which is then subminted to the agency for review. The discussion centres on the overall compliance and inprovements that have been realized by PBR regimes, and the efficiency of the government agencies. The scheme is intended to be more responsive io industry changes and requires more participation by the regulated companies than in prescriptive regimes.

Overall objectives of $P B R$ are to reduce the level of prescriptive measures imposed upon indusing by government. while reducing exposture to the risks of offshore oil and gas exploration and development by placing the means of managing the risk in the hands of the operators. The premise of PBR is that these operators are in a better position to react to changes in technologv and risk than are government agencies.
Apris une mise en contexte ef ume civaluation comparative de la riglementation basice sur te rendemend dans d'aufres scicteurs peitroliers et gaziers en sone extracotiere. on discule de la possibilite' d' 'me' application semblable au Canada. Ces secteurs som passés d'un modele de règlementation prescription a un modele plus axé sur le rendement. Dans un tel régime, le gonvernement énonce les objectifs de rendement de l'indusirie. incluan les objectifs en matiere de conception el d'exploitation ainsi que les attentes en matiere de sicuriti et de protection de l'environnement. C'est ensuite anx socicits ollesmèmes de développer un programme teur permetrum d'alleindre ces objectifs de rendement; le programme' est ensuite prescente a lorganisme aux fins d'inde. La discussion porte sur la conformite gincrale et less améliorations apportées par les regimes basés sur le rendement et l'efficacité des organismes gouvernementaux. Le modèle se veut phus réceptif aur changements de l'indrssiric ef exige une phes grande participation des sociefes reglementes que les rigimes prescriptifs.

Les objectifs géneranar du regime base sur le rendement consistem à reduire le nivedu de mesures prescriptives imposées a l'industric par le gonernement. rout en diminuan l'exposition aux risques de lexploration pitroliere al gazière en zome exiracötière et en assuram le diveloppement en confiam les moyens de gèrer le risque aur exploitants. Laprémisse èram que les exploitunts sont micux placés pour réagir aux changements de kechologic et aux risques que les organismes gonernementuar.

\section{TABLE OF Contents}

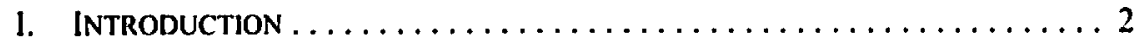

II. JURISDICTIONAL EXPERIENCES $\ldots \ldots \ldots \ldots \ldots \ldots \ldots \ldots \ldots \ldots \ldots$

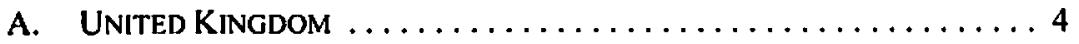

Rob Grant and Will Moreira, Partners, and David Henley, Associate, Stewart MeKelvey, I Halifiax, Nova Scotia. The genesis of this article was a research project jointly undertaken in 2004 by Lloyd's Register and Slewart MeKelvey for Petroleum Research Allantic Canada. The authors gratefully acknowledge the substantial contributions made by Joan Sinclair, Senior Compliance Engineer in the Aberdeen office of Lloyd's Register, and her colleagues in the United Kingdom and Australia, to the work on which this article has heen based, and gratefully acknowledge the agreement of Petroleum Rescarch Atlantic Canada with the authors and Lloyd's Registers for continuing use of intellectual property in that work. Without those contributions and that agreement, this article would not have been possible. 


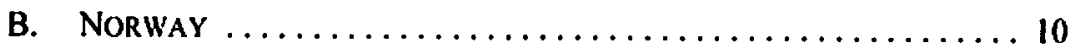

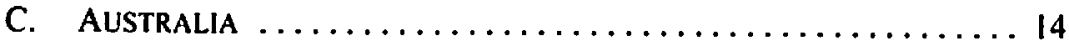

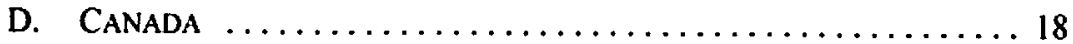

III. Other APplications of Performance-Based Regulation $\ldots \ldots \ldots 25$

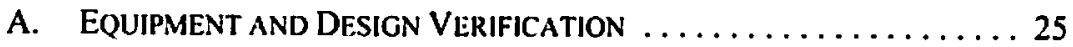

B. INTERNATIONAL MARITIME ORGANIZATION ............. 27

C. ENVIRONMENTAL COMPLIANCE MOIDEL.S $\ldots \ldots \ldots \ldots \ldots \ldots, 28$

IV. Summary and Conclusions . ...................... 29

\section{INTRODUCTION}

The Atlantic Energy Roundtable' announced in February 2005 the launch of the Canadian Offshore Regulatory Renewal Initiative as part of its objective of improving regulatory efficiency, and making the Atlantic offshore energy sector among the most competitive in the world. After researching international and national practice, including the National Energy Board's experience with goal-oriented regulation, the Atlantic Energy Roundtable recommended and received the commitment of the relevant federal and provincial departments to work out an agreed time frame to assess using this approach as a means of modernizing offshore regulations. ${ }^{2}$

While performance-based regulation (PBR) is a relatively novel concept in Canada, highly-evolved and well-functioning PBR regimes exist in the Norwegian and United Kingdom sectors of the North Sea, and in offshore Australia. This observation applies particularly to the regulation of worker and installation safety, although there are examples of application of the PBR model to resource management and environmental protection as well. International exploration and development operators have adapted to these regimes and express a general preference for them over the highly prescriptive safety regulatory models historically adopted and currently applicable in Canadian frontier areas.

The Atlantic Energy Roundtuble was first convened in November 2002 to provide a forum for governments, offshore opcrators, supply and service groups, regulators, and labour to work together to further the development of the Allantic offshore oil and gas industry. Since then it has met three times. At the meeting in February 2005, the Government of Canada was represented by the Honourable R. John Eiford, Minister of Natural Resoures; the Honourable Stephane Dion. Minister of the Environment; the Honourable Gcoff Regan, Minister of lisheries and Oceans; and the Honourable Jerry Pickard. Parliamentary Secretary to the Minister of Industry. The Atlantic Provinces were represented by the Honourable Edward 3. Byme. Minister of Natural Resources. Government of Newfoundland and Labrador; the Honourable Cecil P. Clarke, Minister of Energy, Government of Nova Scotia; and the Honourable Bruce Fitch, Minister of Energy. Government of New Brunswick. Industry was represented by operators, suppliers, and labour, as well as industry associations from across the region. including the Newfoundland Ocean Industrits Association: the Offshore Technologies Associalion of Nova Scotia; and the Canadian Association or Petroleum Producers (Atlantic Energy Roundtable. ReporI of the Implementation Commintec (19) February 2005), online: Natural Resources Canada (NRC) <www.nrean-mean.gc.ca/media/reports/2005/FINAL-AER-Repor_EN.pd? al S [Romedable Report]: NRC, News Release, "Allantic lenergy Roundtable Sels the Stage for Olfshore Energy Investuneni" (19 February 2005), online: NRC <www.nrcan-mcan.gc.ea/media/newreleases/2005/200509_c.htm>).

- The Implementation Commiltee reported the following dates for assessing the application of goal-oriented regulation to offshore regulations: diving, September 2005; submerged pipelines, end of 2005; drilling regulation amendment (well eosts), 2005; drilling and production, end of 2006; geoplysical, 2006 (start 2005); installations/certificates of fitness, 2008 (start 2006); occupational health and safety, 2009 (start 2006) (Roundleable Report, ibid. at 10). 
PBR has been recognized as adding significant flexibility to regulation. While prescriptive regulation deals with the technological and safety requirements at a certain point in time, PBR regimes have the potential to adapt to changing technology. As well, under a PBR system, those who create and work with the risks become responsible for controlling them, rather than government agencies. Among other things, the implementation of PBR has the potential to facilitate technological innovation and efficient use of resources, increase industry initiative in developing and implementing plans of action and self-audits, and could make Canada more attractive to research and development by eliminating prescriptive requirements.

Goal-oriented regulation as implemented by the National Energy Board (NEB) entails a blend of traditional prescriptive regulation with PBR. The NEB's move toward goal-based regulation of certain activities, and in a broader context the federal government's smart regulation program, offers potential for growth of the PBR model in other industries under federal jurisdiction. This article examines experiences and lessons learned in the context of oil and gas regulation offshore of the U.K., Norway, and Australia, and identifies opportunities for expedited, perhaps even aggressive, transition toward PBR models governing workplace safety and installation certification in Canada's Atlantic, Arctic, and Pacific offshore frontier areas.

There is little disagreement about what constitutes prescriptive regulations. The literature outlines that prescriptive regulations "specify the means of accomplishing a regulatory goal, that is, what is to be done, by whom, and precisely how it is to be accomplished." Prescriptive regulations specify "what was to be done ... how it was to be done, what would be inspected, and when it would be inspected, and who would conduct the inspection." The concept of performance-based regulation is consistent across the literature and jurisdictions reviewed. The PBR approach to regulation "sets performance goals, and allows individuals and firms to choose how to meet them,"s or establishes "standards which specify measurable outcomes or performance goals, leaving the means of achieving those outcomes or goals largely to the discretion of the regulated firm or entity."

This article considers the underlying circumstances and environment prompting the shift towards a more performance-based regulatory approach offshore of the U.K., Norway, and Australia, with a view to examining some key considerations in the improvement of regulation of offshore activities in Canada.

Lyle S. Fairbairn, "Performance-Based Regulation in the Canadian Oftshore Oil \& Gas Sector: Background Paper" (28 Octuber 2002) [unpublished, copy on file with authors] at 8.

- Kenneth W. Voltman, "Towards Cioal-Oriented Regulation" (Paper presented at the International Pipeline Conference, Ottawa, 4 Oetober 2000) [unpublished]. online: Nlil3 <www.nebone.gc.ca/newsrooun/Specelies/2000/KWVGoalOrientedRegulationJPC2000_10_04_c.htm>. 


\section{JURISDICTIONAL EXPERIENCES}

\section{A. UNITED KINGDOM}

The current legislative regime for offshore oil and gas activity in the U.K. is predominantly performance based, although a measure of prescription remains in specific areas. The concept of PBR significantly pre-dates its adoption in the offshore industry and can be traced back to the 1972 Robens Report on Safety and Health at Work, which underlies modern U.K. health and safety legislation.

Regulation of the offshore oil and gas exploration and production industry was, from its inception, entirely prescriptive in nature. It is clear, particularly with the benefit of hindsight, that the prescriptive regime applied in the U.K. sector at this time was flawed. Accident rates were extremely high - the combined number of fatalities/serious injuries during the period 1975 to 1984 averaged almost 59 per year, fatalities during the same period averaged almost nine per year and peaked at 17 in 1976. ${ }^{8}$ In addition to these grim statistics, a number of potentially very serious "near miss" catastrophic events were occurring on a regular basis.

The performance-based approach to regulation in the U.K. offshore regulatory regime began as a response to the Piper Alpha disaster on the United Kingdom Continental Shelf. In 1988 an explosion and fire on the Piper Alpha platform resulted in the loss of 167 lives. In the wake of the accident, the U.K. Government commissioned an inquiry headed by Lord Cullen, who released a report in $1990 .{ }^{10}$ Lord Cullen found the regulations at that time did not appropriately address the need to promote effective management of health and safety. He concluded: "Many existing regulations are unduly restrictive in that they are of the type which impose 'solutions' rather than 'objectives' and are out of date in relation to technological advances. This poses a clear danger that compliance takes precedence over wider safety considerations; and that sound innovations are discouraged." The Cullen Report contained 106 recommendations for the improvement of safety on the U.K. Continental Shelf and "provided the blueprint for a new regulatory regime offshore, involving a different regulatory body, major legislative reforms, and the application of a new, goal-setting philosophy to the industry."'2 Specifically, the Health and Safety Executive

3.K., Commiltec on Safety and Health at Work, Safeny and Health at Work: Report of the Commiftee 1970-72, Cmnd 5034, 1972 (Chair: Lord Robens) (London: Her Majesty's Stationery Office, 1972) [Robens Report].

* Den Brown Books, various years; U.K., Oil Industry Accounting Committec, Report on 1991 Accident Statistics (1993); U.K.. Health \& Safety Executive, Offshore Accident and Incident Statistics Report 1993, Offshore Technology Report 010 94-010 (1994).

- R.J. Ledsome, "The Development of Goal-Setting Safety Legislation Following the Cullen Report" (Paper presented at the Second International Conference on Health, Safely \& Environment in Oil \& Gas Exploration and Production. Jakarta, Indonesia, 25-27 January 1994), Socicly of Petroleum Engineers publication SPE 27095 at 143.

10 U.K.. Department of Energy. The P'ublic Inquiry into the Piper Alpha Disuster (Chair: Lord Cullen) (London: Her Majesty's Stationery Oflice, 1990) [Cullen Report].

11 Bid. at para. 21, cited in Ledsome, supra note 9 at 144.

1: lain Todd \& lan Whewell, "The Challenge of Developing and Enforcing a Goal-Setting Regulatory Regime" (Paper presented at the International Conference on Health, Safety and Environment, New Orleans, 9-12 June 1996). Society of Petroleum Engineers publication SPE 35756 at 31. 
(HSE) took over responsibility for regulating offshore health and safety in 1991 and many legislative changes ensued.

This shift in regulatory regime was first suggested in 1972 by the Robens Report, which stated: "There is a role in this field for regulatory law and a role for government action. But these roles should be predominantly concerned not with detailed prescriptions for innumerable day-to-day circumstances but with influencing attitudes and creating a framework for better safety and health organisation and action by industry itself." 13 "Robens concluded that a system of self-regulation provided the most effective way forward for improving occupational health and safety: that those who created and worked with the risks should be responsible for controlling them - not government authorities."14

The Cullen Report's recommendations spawned the Offshore Safety Act $1992^{15}$ which "extended the general purposes of [the Health and Safety at Work etc. Act $1974^{16}$ ] to include safety and ... offshore installations and pipelines ... allowing HSE to use its regulationmaking powers to amend it as necessary to create the new regime."17 The Offshore Installations (Safety Case) Regulations $1992^{18}$ were also developed at this time. From these legislative changes, the U.K. created the performance-based regulatory system that it employs today.

The key recommendation, considered of paramount importance by Lord Cullen, was the introduction of a safety case for each installation. The safety case was required to demonstrate that certain objectives were met, including:

- that an adequate Safety Management System (SMS) be in place, such that the design and the operation of the installation and its equipment were safe;

- that the potential major hazards of the installation and the risks to personnel thereon be identified and appropriate controls provided; and

- that a Temporary Safe Refuge (TSR) and means for full and safe evacuation, escape, and rescue be provided. ${ }^{19}$

\section{Structure of tile UNITID Kingdom's Rlgulatory Protocol}

The U.K.'s offshore regulatory protocol identifies the responsibilities of employers in ensuring the health and safely of employees and others affected by work activities. ${ }^{20}$ The

Robens Report, supra note 7 at para. 28.

Ledsome, supra note 9 at 144.

(U.K.), 1992, c. 15.

(U.K.), 1974, c. 37 [HSWA].

Todd \& Whewell, supro note 12 at 32.

S.I. 1992/2885 [OSCR].

Cullen Report, supra note 10, cited in Ledsome, supra note 9.

S. Nelson ef al., "How the World's Most Comprehensive Goal-Setting Regulatory Regime Works: A Model of the UKCS Regulatory System and its Unique Implications for MODUs" (Paper presented at the SPE/IADC Drilling Conference, Amsterdam, 4-6 March 1997). Society of Petroleum Engineers publication SPE/IADC 37686 at 921. 
fundamental duties of the employers are based on the concept of "reasonable practicability." Anne Sharp's presentation at the Oil and Gas Administration Advisory Council Conference in St. John's in 2000 emphasizes the importance of such a qualifying concept and its critical importance in "securing workable law."

\begin{abstract}
Our courts have interpreled reasonable practicability as requiring judgments which take into account the degree of risk on one hand and on the other the costs in time, trouble and money of averting a risk and unless il can be shown that there's a gross disproportion between thesc, with the risk insignilicant in comparison with cosl, the duty holder must take measures to reduee [the risk] .... [An] individual duty lolder's ability to alford the measures is not considered relevant and it is interesting [on] the point of legal duty that the burden of prool in the courts for reasonable practicability is on the duty holder, not on the prosecuting of authorities. 22
\end{abstract}

The acronym ALARP (As Low as Reasonably Practicable) is also applied to describe the risk-level for which operators must aim. ${ }^{33}$ This approach is prevalent in the definition of "safety case" found in the literature: "The safety case is an analysis by the installation owner of all potential major accidents to which the installation could be exposed and how the risks have been eliminated or mitigated to an acceptable level (as low as reasonably practicable)." $"$ This approach is also employed in Australia and their recent review of offshore safety management provides the following explanation of the safety case mechanism:

The "Safety Case" must establish a strong cnough argument, supported by evidence that will satisfy the regulator, that the operator knows what leclunical and human activity related safety problems exist, how they must be managed and how the saliety of personnel will be assured in the event of an emergency. The salety case must also identify the methods used to monitor and review all activitics to continually improve safety perlormance. Once a saficty case has heen atecepted by the regulator, it forms the "rules" with which the operator must comply in operation of the facility and against which those operations are audited by the regulator. In general, a breach of an acecpted safety case is a breach of the regulations. ${ }^{25}$

: Anne Sharp. "Regulating H ligher Hazards: Exploring the issuts" (PowerPoint pnesentation and transeript from the Workshop on Prescriptive vs. Performance-based Regulatory Regimes for the Canadian off:-

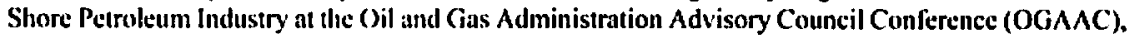
St. John's, Newloundland. 16-17 (Oetober 2000) [unpublished, copy on file with authors].

Ibid.

3 Nelson et al., supra note 20 at 921.

24 G.W. King \& J.D. Dobson, "Well Examination - Self Regulation in a Goal-Setting Environment" (Paper presented at the IADC/SPlE Drilling Conference, Dallas, 3-6 March 1998), Sociely of Petroleum Engincers publication SI'E 51318 at 54 .

3 Austl., Commonwealth, Department of Industry, Science and Resources (ITR), Otrishore Safety and Sccurily. Petroleum and Electricity Division, Funte Arrangements for the Regulation of Offshore Petroleum Sufety: dustraliom Offshore Safety Case Review (Augusl 200I), online: ITR <www.industry.gov:aw/assets/documents/itrinternet/Future_Arrangements_for_regulating_OfTshore_ Petroleum_Safety20040326 10020.pdi> [Australian Future Arrangemenss] at 18 . Generally, a similar protocol is presented in literature regarding both the U.K. and Nonway. However, Nonway does not describe it as "safety caste": rather, the lechnique is referred to as a "risk analysis" or "risk based" approach. See S. Apeland \& T. Aven, "Risk based maintenance optimization: foundational issues" (2000) 67 Reliability Fnginecring \& System Safety 285 at 285. 
According to the $O S C R,{ }^{26}$ operators must submit a safety case to the HSE, which assesses it. The case must be accepted before they can operate and this process must be repeated each time there is a material change or every three years, although it should be noted that the resubmission requirement is likely to be extended to five years under revised regulations currently being prepared by the HSE. Three major bundles of regulations pertain to the U.K. offshore industry in addition to the safety cases: the Offshore Installations and Pipeline Works (Management and Administration) Regulations 1995." the Offshore Installations (Prevention of Fire and Explosion, and Emergency Response) Regulations $1995,^{28}$ and the Offshore Installations and Wells (Design and Construction, etc.) Regulations 1996. ${ }^{29}$

The coming into force of the $O S C R$ occurred in two stages. Implementation of Regulation 11 - "Notification of well operations" - was deferred until 30 November 1995, while the other 16 regulations came into force on 31 May 1993. The $O S C R$ required the production of a Safety Case for the following:

- fixed installations

- mobile installations ${ }^{30}$

- combined operations

- abandonment of fixed installations

In each case, a Schedule of Particulars to be included in the Safety Case was provided. Further regulations dealt with the requirements for management of health and safety and control of major accident hazards (Regulation 8), and the requirement for revision of Safety Cases (Regulation 9).

2. THE OFFSHORE INSTALLATIONS (PREVENTION OF FIRE AND EXPLOSION, AND EMERGENCY RESPONSE) REGULATIONS $1995^{31}$

The next stage in the implementation of the Cullen Report was the passage of PFEER, which came into force on 20 June 1995. The majority of the PFEER is goal-setting in nature; however, some elements of prescription remain.

io Supra note 18.

") S.1. 1995/738 [M/AR].

2* S.I. 1995/743 [PFEER].

* S.I. $1996 / 913[D C R]$.

so Defined within the regulations as *an installation (other than a foating production plat form) which can be moved from place to place without major dismantling or modification, whether or not it has its own motive power" (OSCR, supra note 18, s. 2(1)). 


\section{THE OFFSHORE INSTALLATIONS AND WELLS (DESIGN AND CONSTRUCTION, ETC.) REGULATIONS 1996 32}

The final principal revision of the offshore legislative regime in the U.K. came in 1996 with the introduction of the $D C R$, which came into force on 30 June 1996. The $D C R$ dealt principally with the integrity of offshore installations and their wells.

The lengthiest part of the $D C R$ is Schedule 1 - Additional Requirements. This schedule deals in detail with what are essentially workplace welfare issues, and contains 67 further requirements. The majority of the requirements are goal-setting in nature, with much use of the terms "suitable," "sufficient," "adequate," and "appropriate." However, as in PFEER, some requirements are prescriptive. Schedule 2 of the $D C R$ is also lengthy and details modifications to the 1992 OSCR.

The enactment of the $D C R$ was the final major stage in moving from the previously applying prescriptive regime, as "policed" by the Certifying Authorities under the Certificate of Fitness regime, to a largely goal-setting approach, as evidenced by the need for the operators to decide on the means by which the legislative requirements of the new suite of regulations should be met. Certifying Authorities were replaced by Independent Verification Bodies (IVBs), although it should be noted that the companies providing IVB services were the same as those who had previously been the Certifying Authorities; that is, ship classification societies, such as Lloyd's Register and Det Norske Veritas.

The transition from prescription to goal-setting approaches offshore in the U.K. required a significant change in mindset for everyone involved. However, changes had to be made given the total failure of the previous regime to prevent the Piper Alpha disaster. The reputation of the industry had reached rock bottom and was in urgent need of rehabilitation. Thus, the development of the new goal-selting legislation took place against a general background of goodwill and co-operation among all concerned.

It quickly became clear that the level of expertise that existed at the time within operating companies would, in most cases, be insufficient to conduct many of the studies which were required by the $O S C R$, particularly those involving Quantitative Risk Assessment (QRA). The vast majority of operators were obliged to contract out significant portions of $O S C R$ compliance work to independent safety consulting firms at very high costs. II is estimated that initial production of a single safety case cost in the region of $\mathrm{El}$ million. ${ }^{33}$ The requirement for detailed QRA resulted in the rapid development of computer software tools for the conduct of this type of work, a process which continues to this day. The degree of speciality involved was such that, even when established, use of the QRA model remained with the consulting companies who had developed them and who continued to charge the operators for each change subsequently required.

33 United Kingdom Ofshore Operators Association (UKOOA), "Piper Alpha - A Briefing," online: UKOOA <www.ukooa.co.uk/issues/piperalpha/s0000864.htm>. 
In addition to the substantial expenses associated with risk assessment and safety case production, there were further significant outlays in respect of hardware upgrades necessary to reduce risks to ALARP. These varied platform to platform, depending on the presence and condition of existing plant and equipment, and the outcome of the risk assessments carried out.

Overall, it is estimated that the industry has spent over $f 5$ billion since 1988 on improving offshore safety. ${ }^{34}$

For the regulator, the most significant transition issues surrounded the requirement to increase personnel levels to cope with the influx of safety cases produced by the operating companies. By November 1993, a safety case for every installation had been submitted to the HSE and by November 1995 all had been accepted; ${ }^{35}$ that is, the review period available to the HSE was limited to two years for over 350 fixed and mobile installations. This required a significant increase in manpower, but as a civil service body, the HSE was constrained by nationally applying pay scales for each category of personnel employed by them. It was immediately apparent that HSE also faced stiff competition from industry for the services of suitably qualified staff and specially enhanced pay rates needed to be introduced to attract staff.

The problem of staffing for the bunched submission of safety cases is one with which the HSE continues to grapple to this day. The majority of original safety cases were submitted towards the end of the period allowed for their production (between August and November 1993), and the large workload for the HSE meant that a substantial number were not accepted until towards the end of the period allowed for their review (in $\mathrm{Q} 2 / \mathrm{Q} 3$ of 1995). The requirement for resubmission every three years means that many of these cases are returned to the HSE over approximately six months every third year. Some safety cases have gradually moved out of that cycle (for example, interim resubmission due to "major change" on the installation), but the workload has not yet been successfully smoothed over the years and the HSE still experiences periods of high activity at times of peak re-submission. This problem will be alleviated by the proposed changes to the current $O S C R$ discussed below.

As was always intended, an ongoing process of review of the effectiveness of the $O S C R$ was implemented. The first review, an interim evaluation carried out in 1994/1995,

found that the regulations had a positive impact on of bureaucracy. These findings were endorsed by a full evaluation of the offshore regime, including the OSCR. published in 1999 ... [which concluded that most stakeholders were still of the opinion] that the new legal framework aided effective management of risks, but again that there were doubts about [perceived] excessive regulatory complexity. ${ }^{36}$

Health and Salety Commission (HSC), Revision Of The Offshore Installations (Safely Case) Regulations 1992 (OSCR), Annex HSC/05/8lb of the Drafi Offshore Installations (Safety Case) Regulations 2005 at para. 2, online: HSC <www.hse.gov.uk/aboutus/hsc/meetings/2005/260705/c 81 b.pds. 
These studies were followed up by the HSE, which carried out an internal review of its processes and procedures for reviewing safety cases. This review concluded that many improvements had been initiated to streamline the review process, but that improvements were now required in light of operational experience gained under the new regime. The outcome of this review process was a consultation document published in $2004{ }^{37}$ This document summarized the findings of the various reviews into the efficacy of the safety case regime and proposed replacing the current $O S C R$ with a revised version.

In the consultation document, the HSE described how much of the benefit derived from the $O S C R$ was achieved in the early years of its implementation, but that more recent experience showed a diminishing return in benefits. The cost and effort of preparing and assessing safety cases remained at much the same level. The resources required to administer the case resubmissions every three years might be employed more productively in working towards the attainment of other safely objectives. There was a widespread perception that the safety cases were documents written primarily for the HSE, rather than having significant benefit for the duty holders or their workforces.

As part of its overall review, the HSE addressed a number of fundamental issues associated with the regime, including whether the regulations should be retained at all. After due consideration, the HSE concluded that they are still needed, albeit in an amended format. The HSE further considered whether it was still necessary for safety cases to be formally accepted, and again concluded that withdrawing the "permissioning" element associated with formal acceptance would remove one of the main incentives to comply. The revised regulations thus still require the initial acceptance by the HSE of a safety case in respect of new fixed facilitics and mobile installations first entering U.K. waters and also in cases of material change to existing installations. A major difference between the old and new regulations is the proposed removal of the requirement for resubmission every three years, thus reducing overall the number of resubmissions required. However, it should be noted that the routine resubmission requirement has been replaced with a thorough review every five years, or at intervals "as directed" by the HSE. As yet it is not entirely clear what this will mean in practice, but many operators are nervous that their workload may in fact increase as a result of this change, rather than diminish as had been intended.

\section{B. NORWAY}

There are many commonalities between the Norwegian and U.K. approaches. Exploratory drilling in Norway began in 1966 and in 1969 the first oil was discovered. ${ }^{38}$ In 1972, Parliament established a state-owned oil company, Statoil, to handle the state's financial interests in the activity, and a national directorate, the Norwegian Petroleum Directorate

3. IISC, Publication of Consulhative Document on Revision of the Offihore Installation (Safety Case) Regulanions 1992, Paper HSC/(04/27, online: IISC < swww.hse.gov.uk/consult/condocs/cd198.pdi>; also sec overview, online: IISC <www.hse.gov.uk/aboutus/hsc/meetings/2004/ 110504/c27.pdf>.

is H.T. Olstad, "Risk Assessment Approach to Offshore Safety: Part A - Norwegian Regulatory Philosophy" (Paper presented at the 67th Annual Technical Conference and Exhibition of the Society of Petroleum Engineers, Washington, D.C., 4-7 October 1992), Socicty of Petroleum Engineers publication SPE 24774 at 119. 
(NPD), to carry out government supervision of the industry. The NPD's first objective was to work with other agencies to create a regulatory framework for the offshore industry.

In the mid-1970s Norway entered a transitional period. The regulators were faced with a need for increased inspection activity to mirror substantial increases in industrial activity. Instead they opted to develop and implement what they called at the time a "self-regulation" regime. This was seen as the only option available for regulation based on the funding available for staffing. It has been suggested that Norwegian regulators would require up to ten times the staff under a prescriptive regulatory regime. ${ }^{30}$

The shift to a performance-based approach was augmented in 1985 when the government issued a royal decree obligating the use of self-regulation. ${ }^{40}$ This triggered an aim to create a single agency approach and prompted the reduction of agencies involved from more than ten, to three. The NPD was the appointed coordinator and contact point between industry and regulators. $^{41}$ This consolidation of agencies created a complex network of residual regulations and a decision was made to revamp the system. In 1986, Norway set out to develop a fully performance-based regulatory regime for its offshore industry. This was completed over the ensuing years and continues to be the basis of their operations today.

The current legislative regime in Norway can best be described as predominantly performance-based, although a measure of prescription remains in specific areas. Control of matters relating to health and safety was, until recently, vested in the NPD, which oversaw both the implementation of relevant health and safety legislation as well as the issuing of licences, consents, and approvals. Under delegated authority from the Ministry of Local Government and Labour, the NPD had the power to issue regulations and to conduct overall safety evaluations. In the execution of these duties, the NPD could call on other public bodies, institutions, and companies with special expertise, such as the Norwegian Pollution Control Authority, the Norwegian Social and Health Directorate, and the Norwegian classification society Det Norske Veritas (DNV). However, following a review of state supervisory bodies by the Norwegian Parliament, the supervision of safety and the working environment was separated from the management of petroleum resources. Thus, in January 2004, responsibility for supervision of safety and the working environment was transferred from the NPD to a new body, the Petroleum Safety Authority (PSA), with the NPD continuing, as before, its role in the overall licensing and management of the industry.

Magne Ognedal. "The Goal-Setting Approach to Regulatory Supervision: The Experience of a Safety and Working Envirenment Regulator" (l'owerl'oint presentation and transeript from the Workshop on Prescriptive vs. Performance-based Regulatory Regimes for the Canadian Olf'shere l'etroleum Industry at the Oil and Gas Administration Advisory Council Conference (OC $A$ A (). St. John's. Newfoundland, 16-17 October 2000) [unpublished, cony on lile with authors]. 


\section{Structure of the Norwegian Orishore Regulatory Protocol}

Norway operates under a licensing system whereby licence applicants and the operators with whom they intend to work submit a "risk analysis" to the government for acceptance or consent. This risk analysis outlines the methods by which the operator intends to satisfy the goals set out in the regulations. From the operator's perspective, this gives it the freedom to choose solutions that are optimal for its specific projects and compatible with corporate philosophies. From the authority's perspective, it has the chance to evaluate the competence and capacity of the proposed operator, and may or may not grant the licence. This process is also referred to as acceptance $e^{42}$ or consent. ${ }^{43} \mathrm{~A}$ Norwegian regulator explained how this mechanism promotes good practice:

In this, it is inherent that in the next licensing round, of course we will look at how the licensees and the operator had managed the business, or their safety business, over the years, and you use that when selecting licensees and operaturs. And there are cases in our Norwegian history where operators on the shell' have not been awarded new operatorships because they haven't done the job properly as an operator so far. It is a powerful signal to the company. And they know this. So there are incentives in there, in a way, to do a proper job. ${ }^{44}$

A basic tenet of this approach is the placing of responsibility on the operator and not on the authorities." This is why the government gives consent and not approval, as "approval implies a transfer of responsibility." The literature goes on to explain that, "consent is activity-oriented, i.e. it is concerned with the activity to be executed, and does not imply any kind of approval of installations, equipment $e / c .{ }^{* 47}$

The Norwegian regime also allows for deviation as outlined in the case study described by S.W. Ciaraldi, where he concludes that "[r]isk analysis is a useful tool for input to engineering design, as often simple modifications can enhance safety at minimal or no additional expense." 48 Norwegian authorities expect operators not to deviate from regulations, but they do recognize that deviations are a reality. ${ }^{49}$ If an operator feels that its deviation is acceptable in terms of safety and quality of work environment, it may request "dispensation" from the authorities. If there is agreement that the deviation is warranted, dispensation is granted. If there is no agreement, the regulatory requirements must be fulfilled.

U.A. Kjellen, "The New Risk Analysis Regulations From the Norwegian Petroleum Directoratc: Their Applicability to the Control of Occupational Accidents in Design" (Paper presented at the First Intemational Conference on Health. Safely and Environment, The Haguc, 10-14 November 1991), Society of Petroleum Engineers publication SPE 23277 at 644.

Thor Gunnar Dahle, "The Norwegian Approach to Safety in the Off-Shore Petroleum Activity" (1994)

7 Journal of Loss Prevention in the Process Industrics 379 at 381.

+4 Ognedal, siupra note 39.

ts Dahle, supra note 43 at 380 .

to Hid.

t? Hid. at 381 .

+* S.W. Ciaraldi, "Risk Assessment Approach to Offshore Safety: Part B - The Valhall Firewater System: A Case Study" (Paper presented at the 67/h Annual Technical Conference and Exhibition of the Society of Petroleum Engineers, Washington D.C., 4-7 October 1992), Society of Petroleum Engincers publication SPE 24775 at 128. 


\section{INTERNAL CONTROL. REGULATIONS}

The NPD was established in 1973. While early legislative requirements in its jurisdiction were prescriptive in nature, Norway was ahead of the U.K. in recognizing the potential deficiencies of such an approach. As early as 1975, the /mernal Control Regulations, ${ }^{50}$ which concern safety in petroleum activities, worker protection, and prevention of pollution. required the operator to ensure, via a series of internal control measures, that petroleum activities were conducted in accordance with the various provisions of the legislation.

The NPD focused upon assessing the operator's internal control systems (as opposed to directly assessing how these worked in practice) to ensure that the various activities associated with the licensee's enterprise were correctly reflected in documentation and that evidence existed showing that these were performed in accordance with the law. The NPD performed its assessment in two ways - by audit of the operator's systems and by verification of the output of those systems. The aim at that time was to perform an audit of each operator at least once every threc years though, in practice, a greater frequency was normally achieved.

\section{FramewORK AND SUPPLEMENTARY REGULATIONS}

Although the Norwegian approach has always involved a goal-setting element with regard to the delineation of responsibility and means of compliance assurance, the regulations themselves were not goal-setting in nature and were numerous and complex. By 1985. there were 25 separate sets of highly detailed and prescriptive regulations in place. The NPD then embarked upon a 17-year process of review and simplification of the legislative regime. This process was accelerated by an NPD survey carried out in 1995. which asked the industry about its experience with the existing regulations. The respondents expressed a clear desire for less detailed control and more focus on specific goals. The companies also noted that the rules as they stood contained too much repetition and were too extensive. The end result of the process was the production of five new sets of regulations and the repeal of all 25 earlier prescriptive regulations. The five new regulations, which were produced through a collaboration of the NPD, the Board of Health, and the Norwegian Pollution Control Authority, came into force in January $2002 .^{51}$ The Fromework Regulations ${ }^{52}$ are generally goal-setting in nature and lay out a series of statements and objectives.

\section{OFFSHORE REGULATORY RESPONSIBILITY}

The PSA has sole regulatory authority for all matters relating to health and safety offshore in the Norwegian Sector. This includes both occupational safety issues (the prevention of "slips, trips and falls" types of accident, provision and use of personal protective equipment

w) Nonway, Regulations relating to systematic healh, envirommental and saferly activitic's in enterprises, 6.12.. S.1. 1996/1127 [Imernal Control Regulations].

st Kristin H. Haugen, “Adopting a simplified regime," The Noniegian Petroleum Diary No. 2/2001. online: NPD <www.npd.no/English/Produkter+og+1jenester/Regelverket/nytt_regelverk.htm>.

s. Norway, Regulations relating to Health. Environmen and Safery in the Petroleum Activities (The Framework Regulations), Royal Decree, 31 August 200I. online: NPD < www.npd.no/regelverk/r2002/ frame_e.htm>. 
(PPE)), the establishment of safety committees, and the means by which "major accident" events are prevented. ${ }^{53}$ This latter responsibility extends to issues associated with the integrity of offshore facilities, in terms of their design, construction, and ongoing fitness to operate.

The Norwegian Pollution Control Authority (SFT) has sole responsibility for environmental matters associated with offshore operations. ${ }^{54}$

All the literature concerning Norway emphasizes the importance of trust, confidence, cooperation, and mutual understanding in its performance-based regulatory regime. It also stresses that developing such a regime takes a significant amount of time and requires a change of "mindset" by all parties involved. Authors also discuss the large amount of resources required to achieve a successful performance-based regime and the requirements of achieving this. ${ }^{5 s}$ Norway is still working to improve its regime and created the PSA Norway on 1 January 2004. ${ }^{56}$ This separates the supervision of safety and working environment from the management of resources.

Notwithstanding the very comprehensive nature of Norwegian requirements in this area, a recent NPD report indicated no improvement to overall occupational accident rates over recent years. ${ }^{37}$ It would appear from its website that the PSA plans to address this problem by increased focus on "safety culture" offshore, as opposed to concentrating solely on ensuring regulatory compliance. ${ }^{58}$ As in the U.K., this can be seen as an example of "continuous improvement" in health and safety matters.

\section{Australia}

The current legislative regime in Australia is a mixture of prescription and performancebased requirements, with the latter now predominating. The regime is currently somewhat in a state of flux, with changes proposed to both the regulator and to the regulations.

Putroleum Sufety Authority Norway (PSAN), "Facts about the Petroleum Sufely Authority Norway (PSA)," online: PSAN <WWw.ptil.no/Lnglish/Helse+miljo+og+sikkerhet/HMS-aktuelt/fakta_om petrolcumstilsynet.htm>. See also "Objectives and duties," online: PSAN <www.ptil.no/English/Om+ PetroleumstilsyneU Organisasjon/Maal+og+oppgaver/Objective+and+duties.htm>. Nonwegian Pollution Control Authority (SFT), "Our tasks," online: SFT <www.st.no/english/ organization/tasks`. See also "Working to reduce pollution," online: SFT <www.sf.no/publikasjoner/ andre/2117/1a2117.pdP.

"Sec e.g. Ognedal, supra note 39.

so PSAN, "The PSA's history," online: PSAN <www.ptil.no/English/OmtPetrolcumstilsyneV Organisasjon/Petroleumstilsynet+historie/ptils_historic.htm>.

NPD, Ofshore Nonway NPD's Anmmal Report 2002, see s. 2.1 "Personal injuries," online: NPD <www.npd.no/English/Produklertog+ljenester/Publikasjoner/ODstaarsberetning/2002/2Helse\%2c+ milj\%l;8+og+sikkerhet.htm>.

PSAN, "Launching theme pamphlet on HSLE culture," (30 April 2004), onlinc: PSAN <www.ptil.no/ English/Produkter+og+tjenester/Publikasjoner/4_temahefte_hms_kultur_relansert.hım>; see also "Theme Pamphlet: HSE and culture," online: PSAN < www.ptil.no/NR/rdonlyres/A9SD6036-8E4243F3-9AFA-F422CD868A45/0/IEScultureNY.pdis. 
In 1979, the Commonwealth and the states agreed to a division of offshore powers and responsibilities referred to as the Offshore Constitutional Setrlemen/(OCS). ${ }^{59}$ The states and Northern Territory were granted title to all waters landward of the three-nautical-mile limit and have the same power to legislate over these coastal waters as they do over their land territory. The OCS also confirmed the jurisdiction of the Commonwealth over waters outside the three-nautical-mile limit. ${ }^{60}$ With the exception of Western Australia, cach jurisdiction has applied its own occupational health and safety law in its respective coastal waters, with the Commonwealth Petroleum (Submerged Lands) Acr applying in Commonwealth waters (Western Australia has applied Schedule 7 of the PSLA). As a result, companies with offshore facilities in more than one jurisdiction have had to meet the requirements of different laws.

Like the U.K., Australia's development of a performance-based regime was triggered by the Piper Alpha disaster of 1988. Specific details about the development of Australia's regime are scarce in the materials; however, the Australian presentation at the OGAAC Workshop in St. John's in 2000 by Paul Butler provides a brief account of its development. ${ }^{62}$ After the Piper Alpha accident, Australia decided a performance-based regime was needed. However, as Butler expressed in his presentation, the magnitude of such an undertaking was not understood. He commented: "In retrospect, I think we [had] a superficial appreciation of what we ought to do post Piper Alpha and we've caused ourselves a lot of problems because of that. What we really got wrong, I think, was how we were going to put this regime in place." ${ }^{63}$ He identified the problems Australia has had balancing interests between the State and Commonwealth Governments, and how this is exacerbated because Australia has three very remote areas of offshore production in three different state jurisdictions. Their regulatory regime structure was complex with states having day-to-day responsibilities and the federal government having overall responsibility. As well, there was a combination of joint authorities regulating the offshore industry.

The primary instrument in Australia for offshore legislation is the PSLA, ${ }^{\text {to }}$ originally passed in 1967 and amended many times since. In its original form, the PSLA was entirely prescriptive in nature; over time, the majority of the prescriptive elements have been repealed and replaced with goal-setting requirements.

The OCS is principally implemented through the Coastal Waters (State Titie) Ad 1980 (Cth.), the Coastal Waters (State Powers) Act 1980 (Ch.), the Coastal Waters (Northern Territory Tille) Act 1980 (Cth.), and the Coastal Waters (Northern Territory Powers) Act 1980 (Cth.).

Austl., Commonwealth, Environment Australia, Caring. Understanding. Using Wiscly: Australia's Oceans Policy, Appendix 2, “Legal and Constitutional Framework of Australia's Marine Areas," online: National Oceans Office <www.oceans.gov.au/content_policy_vl/page_013.jsp>. Whole report available online: National Occans Olfice <www.oceans.gov.aw/content_policy_vl/default.jsp> [Caring. Understanding. Using Wisely].

(Cth.), online: Australian Government. Attomey-General's Department <www.comlaw.gov.au/comlaw/ Legislation/ActCompilation l.nsf/framelodgmentattachments/A379L3B7AD53FD46CA256FBC $00827779>$ [PSLA].

Paul Butler. "Offshore Petroleum Regulation: The Australian Expericnec" (PowerPoint presentation and Iranscript from the Workshop on Prescriptive vs. Performance-based Regulatory Regimes lor the Canadian Offshore Petroleum Industry at the Oil and Gas Administration Advisory Council Conference (OGAAC), St. John's, Newfoundland, 16-17 Oclober 2000) [unpublished, copy on file with authors]. 
The most far-reaching of these amendments was the passing, in 1996, of the PSLA (Managemen of Safety on Offshore Facilities) Regulations 1996. ${ }^{\text {ss }}$ These regulations introduced a requirement of safety cases for offshore facilities. The catalyst for this change was the Piper Alpha disaster in the U.K. and the subsequent recommendations of the Cullen Report. $^{66}$

In 2001, following an accident at Australia's Longford oilfield pipeline (an onshore operation) where two men were killed, the Offshore Safety and Security, Petroleum and Electricity Division of the Australian Department of Industry, Science and Resources released the publication, Future Arrangements for The Regulation of Offshore Petroleum Safety. ${ }^{.7}$ Its basic conclusion was that "the Australian legal and administrative framework, and the day to day application of this framework, for regulation of health, safety and environment in the offshore petroleum industry is complicated and insufficient to ensure appropriate, effective and cost efficient regulation of the offshore petroleum industry." Obviously this indicated a need for change in Australia, a matter that has since been undertaken. In August 2001, the Australian Future Arrangements was prepared for the Commonwealth Government. The report included a recommendation that a national petroleum regulatory authority should be developed to oversee the regulation of safety in Commonwealth offshore waters. This recommendation has been adopted and a new body, the National Offshore Petroleum Safety Authority (NOPSA), came into being on 1 January 2005 through the Petroleum (Submerged Lands) Amendment Act. ${ }^{69}$

\section{OFFSHORE REGULATORY RESPONSIBILITY}

Creation of the NOPSA means that the current division of responsibility between Commonwealth and state/territorial waters will be removed. The NOPSA will regulate safety for offshore oil and gas facilities (production facilities, drilling rigs, and oil and gas pipeline construction), and will thus constitute a single safety regulator for these offshore facilities in Australia. The NOPSA will be an independent authority and has been set up by legislation as a Commonwealth agency.

The Western Australia Department of Industry and Resources (DoIR) will continue to regulate safety for petroleum exploration (seismic and drilling), development, production facilities, and activities on the Western Australian islands and onshore mainland Western Australia. DolR will also continue to administer safety in relation to petroleum pipelines (transmission) onshore and offshore, except for offshore pipeline construction (safety regulated by the NOPSA).

Putroleum (Submerged Lands) (Management of Safety on Ofshore Facilities) Regulations 1996 (Cth.), online: Australian Govenment. Atorney-General <www.comlaw.gov.au/comlaw/legislation/ Iegislativcinstrumentcompilation I,ns///ramelodgmentatlachments/DVFD3|P170057DB35CA25706E0 02ACBS4>.

« Cullen Report, supwa nole 10. Information on the Piper Alpha disaster also available online: BBC <hltp://news.bbc.co.uk/onthisday/hi/dates/stories/july/6/newsid_3017000/3017294.stm>.

Australian Future Arrangements, supra note 25.

thid. at 5-6 summarizing the findings of the Independent Review Team..

Petroleum (Submerged Lands) Amendmem Act 2003 (Cth.), online: Australian Government, AltomeyGeneral <www.comlaw.gov.aw/ComLaw/Legislation/Act l.nsf/all/search/A0100868CB3FIC95CA256F 7201010BB79? OpenDocument\&:VIFWCAT $=$ item\&COUNT $=999 \& S T A R T=1>$. 
The Western Australia DoIR will continue to administer regulatory functions, such as issuing (and amending) petroleum exploration and production titles, pipeline licences, regulation of resource management, and environmental management in relation to all petroleum sites and activities in the state onshore and offshore areas, including the Commonwealth adjacent waters.

This transfer of responsibilities has necessitated a considerable amount of legislative development and revision. The Commonwealth amendments to legislation for the creation of the NOPSA have been passed. Legislation establishing the fees through which the NOPSA will be financed by the industry is currently moving forward. Amendments to state legislation are being drafted to incorporate changes to the Commonwealth legislation (including mirroring the Commonwealth PSLA regulations in the state/Northern Territory PSLAs), thus removing the split responsibility between Commonwealth and state/territorial waters.

The NOPSA will assume responsibility for both occupational safety issues (the prevention of "slips, trips and falls" types of accidents, provision and use of Personal Protective Equipment (PPE)), the establishment of safety and other committees, and the means by which "major accident" events are prevented. This latter responsibility extends to issues associated with the integrity of offshore facilities, in terms of their design, construction, and ongoing fitness to operate. Environmental legislation is presently administered by the various state/territorial Designated Authorities, although it has been suggested that the NOPSA may, in the future, also assume responsibility for environmental matters.

The limited literature regarding the regulatory structure of this jurisdiction details the problems with the Australian approach and provides recommendations on how to improve and change. It was found that there were too many regulatory instruments and directions applicable to Australian offshore petroleum activities, overlap of application and jurisdiction, unnecessary prescription, inconsistent interpretation by regulators, and guidelines were often applied as if they were regulations. ${ }^{70} \mathrm{With}$ respect to the offshore regulatory structure, many issues were identified relating to the regulator. The role of the designated authority was not well defined and different regulators took significantly different approaches. The processes followed by regulators were not sufficiently transparent and the resources available to them were not sufficient so as to allow the recruitment of a critical mass of competent and qualified personnel. It was also noted that conflicts of interest could be created when the same consultants were used to assess safety cases that were involved in safety case preparation. $^{71}$

These foregoing insights could be invaluable during the creation phase of a performancebased regime in Canada. Such sentiments were expressed by Butler in the opening remarks of his presentation in 2000 when he said: "Considering the strong similarities between the way Canada is structured and the way Australia is structured and the fact that we're five or 
six years ahead of you along this performance-based path, we thought we couldn't really, in all fairness, allow you to make the same mistakes that we've made."

\section{Canada}

\section{CURRENT OfFSHORE REGULATORY REGiME}

The Canadian Oil and Gas Operations $A C t,{ }^{73}$ for which the NEB is responsible, applies in respect of the exploration and drilling for and the production, conservation, processing, and transportation of oil and gas in: (a) the Northwest Territories, Nunavut and Sable Island, and (b) submarine areas, not within a province, in the internal waters of Canada, the territorial sea of Canada, or the continental shelf of Canada. This means that the COGOA essentially regulates areas not within a province, including offshore areas. However, the offshore areas of both Nova Scotia and Newfoundland and Labrador are excluded by federal/provincial agreements. The Canada-Nova Scotia Offshore Petroleum Resources Accord Implementation (Nova Scotia) ACr ${ }^{74}$ and the Canada-Newfoundland Atlantic Accord Implementation $A c^{75}$ (collectively, the Accord Acts) implement agreements between the Governments of Newfoundland and Labrador, Nova Scotia, and Canada in regard to management of offshore petroleum resources and revenue. In this fashion, the offshore areas of Nova Scotia and Newfoundland and Labrador are largely regulated by the provincial Offshore Petroleum Boards, though there is some overlap with the NEB. The Accord Acts are mirrored at both the federal and provincial level to avoid questions of jurisdiction between the provinces and the federal government. Most of the provisions of the COGOA are similar to those in the Accord Acts.

A variety of regulations have been enacted pursuant to the Accord Acls, including:

- The Nova Scotia Offshore Area Petroleum Diving Regulations ${ }^{76}$ and the Newfoundland Offshore Area Petroleum Diving Regulations ${ }^{77}$ (collectively, the Diving Regulations). Similar to Norway and Australia, but unlike the U.K., these regulations apply to any diving operation conducted in the offshore area in connection with the exploration or drilling for or the production, conservation, processing, or transportation of petroleum. These regulations are very specific and clearly prescriptive.

- The Nova Scotia Offshore Area Petroleum Installations Regulations ${ }^{78}$ and the Newfoundland Offshore Area Petroleum Installations Regulations ${ }^{79}$ deal with the construction and operation of a diving installation, a drilling installation, a production installation, or an accommodation installation, and outline an overall

$\because \quad$ Butler, supra nole 62.

"R.S.C. 1985, c. 0.7 [COGOA].

" R.S.C. 1998, c. 28 [NSO'RA].

3 R.S.C. 1987, c. 3 [AA/A].

is S.O.R/1995-189.

" S.O.R./1988-601.

i* S.O.R/1995-191.

is S.O.R/1995-104. 
objective of providing for the safety of personnel, minimizing damage to the environment, and enabling easy access to the equipment. Each section begins with a general objective or goal, but much of the regulation is prescriptive, in that it details specific requirements.

- The Nova Scotia Offshore Area Petroleum Drilling Regulations ${ }^{80}$ and the Newfoundland Offshore Area Petroleum Drilling Regulations ${ }^{81}$ (collectively, the Drilling Regulations). These apply to operators who explore or drill for petroleum and to every well and test hole drilled under the Accord Acts. The requirements for obtaining drilling program authorization and approval to drill are specified in the Drilling Regulations and the various parts of the regulations deal with operational requirements, safety and training of personnel, operational records and reports, well evaluation, well or test hole termination, deposition of samples from a well, and final well reports. These regulations are very detailed and largely prescriptive.

- The Nova Scotia Offshore Petroleum Production and Conservation Regulations ${ }^{\mathrm{k2}}$ and the Newfoundland Offshore Petroleum Production and Conservation Regulutions ${ }^{\text {B3 }}$ (collectively, the Production and Conservation Regulations) outline the requirements for a production operations authorization. The regulations also define the information submission requirements for various aspects of production and require submission to the Chief Safety Officer or the Chief Conservation Officer of certain information in respect of well, pool and field evaluation, operation of wells, conservation requirements, production rates, measurements and testing, environmental requirements, operations, safety and training, and inspections. These regulations are a hybrid of prescriptive and goal-based provisions. Some portions provide general direction.

- The Nova Scotia Offshore Area Petroleum Geophysical Operations Regulations ${ }^{34}$ and the Newfoundland Offshore Area Petroleum Geophysical Operations Regulations ${ }^{85}$ outline the process and method for obtaining a geophysical operation authorization. These regulations have parts dealing with geophysical operations, occupational health and safety, reporting requirements, and accidents. They are largely prescriptive in that the requirements are explicit and detailed.

- The Nova Scotia Offsinore Cerrificate of Fimess Regulations ${ }^{86}$ and the Newfoundland Offshore Certificate of Fimess Regulations ${ }^{\mathrm{k7}}$ deal with the issuance of certificates of fitness for petroleum production, drilling, accommodation, and diving installations in the offshore areas. Certificates of fitness are required pursuant to the Production and Conservation Regulations, the Drilling Regulations 
(where a production installation includes a drilling rig), and the Diving Regulations (where a production installation includes a dependant diving system). The regulations contain some general requirements, such as the requirement that the installations be "fit for the purpose for which it is to be used and can be operated safely without polluting the environment." ${ }^{188}$ However, many of the criteria to be satisfied are expressed through cross-references as compliance with the provisions of other relevant regulations.

\section{OCCUpational Health AND Safety}

In Canada, occupational health and safety (OHS) is governed by both provincial and joint federal/provincial regulation. The Canada-Nova Scotia Offshore Petroleum Board (CNSOPB) Occupational Health and Safety Requirements ${ }^{89}$ is a guidance document that defines the duties and responsibilities for all parties involved with the exploration and exploitation of petroleum in the offshore area and provides a framework for participation, transfer of information, and refusal of unsafe work. The Requirements begin with a general statement of principles and describe obligations and duties in a very general fashion. They become more prescriptive as they deal with specific OHS matters. The Requirements attach and reference draft regulations. The draft regulations would apply in respect of all OHS matters relating to the exploration, drilling, production, conservation, processing, or transportation of petroleum in the of ftshore area. There are limited general statements at the beginning of the regulation (for example in the section on general safety) that set broad obligations. However, the vast majority of the draft regulation articulates specific and detailed requirements. The draft Newfoundland Petroleum Occupational Safety and Health Regulations ${ }^{90}$ are identical to the draft regulations found at Part 11 of the Requirements.

The federal $A c c o r d A c t s^{91}$ currently make the provincial legislation of Nova Scotia and Newfoundland and Labrador applicable offshore with respect to any marine installation or structure that is within the offshore area in connection with the exploration, drilling, production, conservation, or processing of petroleum within the offshore area. The legislation of the respective provinces is defined within the Accord Acts to include specific provincial statutes, including the OHS legislation.

The Occupational Health and Safety $A t^{42}$ deals with the coordination, administration, and enforcement of OHS in Nova Scotia. The Act imposes duties on employers, employees, selfemployed persons, constructors, contractors, professionals, owners, suppliers, and providers of OHS services. The Occupational Safety General Regulations ${ }^{93}$ provide standards and

Ibid., s. 4(I)(a)(ii).

Canada, Canada-Nova Scotia O/fshore Petroleum Board, Nova Scotia Offshore Petroleum Occupational Health \& Safety Requirements (December 2000), online: Canada-Nova Scotia Offshore Petroleum Board <www.cnsopb.ns.ea/regulatory/pdf/OHSRequirments.pdi> [Requiremenis].

Newloundland \& Labrador, Department of Natural Resources (DNR), Developing an Energy Plan for Newfoundland and Labrator: P'ublic Discussion Paper (November 2005), ontine: DNR <www.nr. gov.nl.ca/energyplan/papers/discussionpaper.pdß.

Supra notes 74-75.

R.S.N.S. 1996, c. 7 , s. 1 .

N.S. Reg. $4 / 2004$. 
requirements for all aspects of the workplace (for example, ventilation and lighting). Many of the provisions are goal based without providing mandatory direction or means.

However, in the fall 2003 sitting of the Nova Scotia legislature, a proposed amendment to the provincial $A c c o r d A C t^{94}$ was introduced revising the $A C t$ to state that, among other legislation, the provincial Occupational Health and Safety $A c t$ does not apply on a marine installation or structure that is within the offshore area in connection with the exploration, drilling, production, conservation, or processing of petroleum within the offshore area. The bill only completed first reading before the session ended. The bill has been reintroduced and the Government of Nova Scotia is expected to pass this legislation and both the federal government and Newfoundland and Labrador will follow suit with similar amendments.

The amendments introduce a new Part IIIA to the Act dealing with OHS in respect of the exploration, drilling, production, conservation, or processing of petroleum within the offshore area. The structure of Part IIIA is initially goal based, noting that its goal is to prevent accident and injury to health, in particular by:

(a) allocating responsibility for occupational health and safety among the various participants involved in work or activitics in the offshore area; and

(b) establishing a framework for participants to exercise their rights and carry out their obligations under this Part. 95

Part IIIA of the amended $A c t$ sets out principles for allocation of responsibility. It requires that the operator develop a written OHS policy and an OHS system that is "adapted to the circumstances of the work or activity." with an extensive list of mandatory requirements, though these too are expressed in a general manner. Duties are also imposed upon employers and other involved parties. These duties are generally more detailed than those imposed on the operator. Later provisions of Part IIIA of the amended $A C t$ are more specific and clearly prescriptive, such as those dealing with communication of information. The goal-based portions of Part IIIA of the amended $A C t$ could support performance-based regulations; however, other aspects of the amended $\mathrm{Act}$ will by their nature necessitate some prescriptive regulation.

The amendments to the provincial Accord Act provide that the Oil and Gas Occupational Health and Safety Regulations (OGOHS Regulations) $)^{47}$ will apply in respect of any marine installation or structure pending replacement by regulations enacted under the amended $A c t$. The OGOHS Regulations are enacted pursuant to the federal Canada Labour Code ${ }^{48}$ and deal with OHS of employees employed in or in connection with exploration, drilling, production, conservation, processing, or transportation of oil or gas in Canada. The regulations do not apply in respect of employees employed in the operation of ships or aircraft and without this

13ill 37, Canada-Nova Scotia Offshore Petroleum Resources Accord /mplementation (Nova Scotia) ACt - amended, Ist Sess., 59 Leg., Nova Seolia, 2003 [Bill 37]; reintroduced 8 May 2006, 2 d Sess., 59 Leg. as Bill 41; reintroduced 30 June 2006, Ist Sess., $60 \mathrm{Leg}$. as Bill 18. 
amendment would not apply offshore Atlantic Canada. The regulations provide very detailed and prescriptive standards in respect of OHS. Thus, if the amendments to the provincial Accord Acts are passed, the applicable regulations will continue to be prescriptive until new regulations are enacted. It should be noted that the NEB is in the process of reviewing the OGOHS Regulations with the view to making them more goal-oriented.

The proposed Part IIIA of the amended Accord Act is similar to the U.K. HSWA, ${ }^{99}$ both in approach and in many provisions. However, while in some places the $H S W A$ leans toward a goal based approach, the OHS provisions of the amended Accord Act veer toward a prescriptive approach. As is evident from the U.K. example, much will depend on the approach adopted in supporting regulations.

\section{ENVIRONMENTAL REGULATION}

The Canadian Environmental Assessment $A c t^{100}$ is of general application. An environmental assessment of a project is required, among other things, before a federal authority issues a permit or licence, grants an approval, or takes any other action for the purpose of enabling the project to be carried out. The CNSOPB and Canadian Newfoundland Offshore Petroleum Board (CNOPB) have been prescribed by regulation to be federal authorities.

In essence, authorization for most projects related to oil and gas must be obtained from one of the Boards (CNSOPB, CNOPB, or the NEB). This requirement for approval from a federal authority generally triggers a requirement for an environmental assessment and approval under the Canadian Environmental Assessment Act.

\section{REGULATORY DEVELOPMENT}

The differing approaches taken by the U.K. and Canada in their offshore regulatory regimes may, in part, be attributed to the different conclusions reached by the two jurisdictions' commissions of inquiry into roughly contemporaneous and equally tragic casualties.

The U.K.'s inquiry into the Piper Alpha fire of 6 July 1988 was reviewed above. ${ }^{101}$ In Canada, the seminal casualty was the capsizing and sinking on 15 February 1982 of the semisubmersible drilling unit Ocean Ranger, with loss of all 84 lives on board. A Commission of Inquiry was established jointly by the Governments of Canada and of Newfoundland and Labrador and was given a two-part mandate: first, to report on the causes of and reasons for the loss of the Ocean Ranger itself; and second, to inquire into and report upon "marine and drilling aspects of practices and procedures in respect of offshore drilling operations on the Continental Shelf off Newfoundland and Labrador." Ultimately, the Commission broadly interpreted the scope of its second mandate to address "Safety Offshore Eastern Canada." 
The Commission reported separately on each aspect of its mandate, on the first phase in August 1984 and on the second phase in June $1985 .^{102}$

In its first report, the Commission attributed the specific casualty to a combination of design, operational, and personnel training deficiencies, none of which had been identified or remedied by the rig owner, the exploration operator, the classification society, the flag state maritime regulator, or the coastal state oil and gas operations regulators (which at the time comprised separate Canadian and Newfoundland agencies).

In its second, and more general, report the Commission concluded that Canada needed a uniquely Canadian offshore safety regulatory regime. This conclusion was based on the fact that existing laws were directed primarily to onshore oil and gas operations and that a uniquely hazardous environment existed in the northwest Atlantic. Regulations and standards developed for other parts of the world were not necessarily relevant to this environment. The Commission did not recommend that the regime should be prescriptive in nature, but it did not address itself, as did Lord Cullen's later-in-time report on the Piper Alpha casualty, to the safety risks that are inherent in an unduly prescriptive regulatory model. The regulatory model proposed by the Ocean Ranger Commission may be gleaned from the Commission's Recommendation 81:

\section{That}

(a) more extensive regulations and guidanee notes be developed.

(b) insofar as it is practical, regulations be framed in terms of prineiples, performance standurds and criteria, which, supplemented with a comprehensive body of guidance noles, are made available in consolidated form. ${ }^{103}$

Context for this recommendation is to be found in the discussion that immediately preceded it:

One of the basic purposes of the regulatory process is to provide a framew ork within which the offshore industry can function with full and timely knowledge of the rules applicable at any given time. The nature of the Canadian mode of regulating the oftshore is less developed than that of other jurisdictions examined. Without the extension of her general body of laws offshore. Canada has relied primarily upon the Oil and Gas Production and Conservation Act which is as applicable of Tshore as on land. Regulations issued under that statute have been rather modest in number and in the extent of their application. The dratting and promulgation of regulations are subjected to an unconscionably lengthy process with a consequent loss of flexibility. The prime instrument of control has been the application-permit process and stipulations in that process are being used instead of regulations and guidance notes. Indeed, instructions are often issued by

Canada, Royal Commission on the Ocean Ranger Marine Disaster, vol. 1, Reporf Ome: The Loss of the Semisubmersible Drill Rig Occan Ranger and ils Crew' (St. John"s. Nild.: Royal Commission on the Ocean Ranger Marine Disaster. 1984) (Ocean Ronger Commission Report 1): and Royal Commission on the Ocean Ranger Marine Disaster, Reporf Two: Safery Offshore Fastern Comodu. Conference Proceedings 1984, vol. 4 (St. John's, Nald.: Royal Commission on the Ocean Ranger Marine Disaster. 1985) [Ocean Ranger Commission Report 2, or collectively, the Octan Ranger Commission Reports]. The quotation of the terms of reference is from Ocean Ranger Commission Report $1, A$ ppendix $A$ at 166. 
word of mouth, telex, letter or other means. Il is consequently difficult for industry to discover what controls are, in fact, being enforced. The application of law and regulations becomes a private matter between the regulator and the operator. An operator needs to know clearly the requirements which he and the other operators are expected to observe. These requirements, expressed primarily in regulations and explanatory guidance notes, need to be flexible to be responsive to changing technology but also to possess the level of certainty required by those who are regulated. ${ }^{104}$

It is a fair comment, especially with the benefit of 20 years' hindsight, that lawmakers took more heed of the certainty than the flexibility aspects of the above commentary. It is a matter of record in Canada that highly detailed and largely prescriptive regulations were promulgated in the period following release of the Ocean Ranger Commission Reports, and that those regulations, largely verbatim, were adopted and became applicable in the Newfoundland and Nova Scotia offshore areas as the joint federal-provincial regulatory regimes for which the Accord Acts provided came to be established. The specific regulations may be considered to be part of the legacy of the government's response to the Ocean Ranger incident. ${ }^{105}$

There has been some movement within Canada toward performance-based regulation. By way of example, the draft revised Canada Oil and Gas Diving Regulations and Guidance Notes ${ }^{106}$ are part of the NEB's goal-oriented regulation program. ${ }^{107}$ While developed for the COGOA, ${ }^{108}$ they were developed in conjunction with the CNOPB and the CNSOPB with a view to implementation of similar regulations within their jurisdiction. They were issued in draft in 1999 and are intended both to update the existing regulations and to shift to a goaloriented approach.

The Guidance Notes explain that operators are responsible for developing appropriate standards and procedures to ensure that the required results are achieved. They encourage

\section{Ibid.}

The prescriptive regulations were developed in spite of recommendations in the Ocean Ranger Commission Reports. See also the Report of the Minister's Task Force on Ocean Ranger Regulatory Recommendations (Ministry of Energy, Mines and Resources, "The Promotion and Enhancement of Safety in Oil and Gas Operations on Canadian Frontier Lands" (31 July 1986)). This report was even more specific in its recommendations, stating at 93 that "safety regulations be performance-oriented, reflecting, inter alia, that the specific means for ensuring safety are the responsibility of industry."

S.O.R./1988-600, online: Department of Justice Canada <hup://laws.justice.gc.ca/en/O-7/SOR-88600/39002.html>; NEB, Guidance Notes for the Canada Oil and Gas Diving Regulations, Drafl (June 1999), online: NEB <www.one.ge.ca/ActsRegulations/divgdn_e.htm\#GuidanceNotes> [Guidance Notes]. See also "Amendments to Regulations" (Octoher 2005) Regularory Agenda, online: NEB

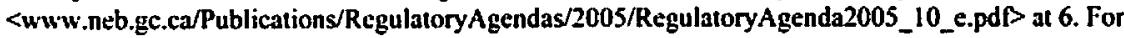
more information on this matter, refer to item 4 under "Amendments to Regulations and Rules" in the May 2001 issuc of Regulatory Agenda, online: NEB < www.neb.gc.ca/Publications/RegulatoryAgendas' 2001/RegulatoryAgenda2001_05_e.pdrs at $7[$ Regulatony Agenda]. For current guidelines see online: NEB < www.neb-one.ge.ca/ActsRegulations/index_...htm\#RulesRegulationsGuidelinesGuidanceNotes MemorandaGuidance>. An example of the dialogue with industry associations can be found at Project Working Group. "Detailed Response to 29 June 2005 CAPP Comments on the Draf Goal Oriented DP" Regs" (March 2006), online: NEB < www.neb-one.gc.ca/ActsRegulations/COGOA/GoalOrientedDPR DraflMarch2006_e.pds.

The NEB has coined the term "goal-oriented regulation" and uses it to "refer to regulations which contain a mix of prescriptive and goal based [performance-based] requirements" (see Ken Paulson, "Goal Based Regulation of Pipelines in Canada"(NEB, 2004) [unpublished, copy on file with authors]). Supra note 73 . 
the use of widely accepted standard procedures. The Guidance Notes state: "Following the practical advice and suggestions contained in the Guidance Notes will facilitate compliance with the Regulations. Guidance Notes are not mandatory and alternative methods may be utilized to comply with the Regulations." 109 The draft regulations and the Guidance Notes were prepared in consultation with the Boards, other government departments, and the Canadian diving community. "10

The regulation does not specify what is necessary to secure authorization, other than stating that the operator shall detail the manner in which the equipment, personnel, methods, measures, or standards proposed will provide the equivalent level of safety and protection of the environment to that provided by compliance with the regulations. In the existing regulations an operator is expected to comply with the detailed requirements throughout the remainder of the regulation in order to secure authorization. Many of the prescriptive requirements in the existing regulations are removed to the Guidance Notes, where it is no longer mandatory. The draft regulation has not yet been implemented.

The most common criticism of prescriptive regulation in the Atlantic Canada offshore area is that it fails to keep pace with technological change and advances in industry practices. The powers of the Chief Safety Officer and Chief Conservation Officer to authorize changes or to grant exemptions (which are administrated through a regulatory query form (RQF)) to some extent ameliorate this disadvantage.

The RQF process, however, is perceived as time consuming, costly, and uncertain. Operators have reverted to prescriptive requirements on occasion rather than face the costs and delays associated with oblaining approvals for a preferred means of operating. Criticisms by industry of inconsistency in approvals by the CNSOPB and CNOPB in handling RQFs may be dulled by recent efforts through industry associations to notify the industry of decisions taken by the Boards. There still remains a prevalent perception that the response to a request for change will vary depending upon the Board representative who is responsible for dealing with it. Industry also questions the qualifications of the regulators to perform appropriate technical review of many change requests. The duplication of efforts and costs entailed in the Boards obtaining outside expert assistance in reviews of RQFs does not enhance the efficiency of the regulatory regime.

\section{Other Applications of Performance-Based Regulation}

\section{A. EQuipment and DESIGN Verification}

There are, in The Framework Regulations" in Norway, provisions for "verification" to be carried out. ${ }^{12}$ These requirements relate solely to the design of an installation and cover such matters as review of calculations, drawings, and fabrication by examining what has been done by the design contractor and by having independent or in-house calculations 
carried out. Verification may also cover testing of products and systems and may include control of calculations, drawings, and fabrication by examining what has been done and/or by having independent or in-house calculations carried out. Verification can also include testing of products and systems. In common with the U.K., ${ }^{113}$ such "independent design review" that is carried out is done by classification societies - in Norway this is almost invariably DNV, which holds close to a monopoly position within that country.

A unique feature of the Norwegian system is the direct involvement of the PSA in "ongoing" verification processes. The Norwegians have recently begun a compulsory process whereby operators must apply for an acknowledgement of compliance in relation to their facilities. Although falling short of a safety case submission as understood in the U.K. and Australia, this process requires operators to demonstrate that they have carried out satisfactory assessment of compliance with the HSE regulatory requirements using the necessary analyses and verifications. They must also identify and document a complete list of deviations from any of the regulatory requirements and provide evidence that their employees have been involved in the process of preparing the application. Part of the process of obtaining an acknowledgment of compliance provides for the carrying out of verification activities by the PSA. These involve a system of offshore visits and inspection/audit of specific areas of the installation safety management system. ${ }^{1 / 4}$

In Australia there is also a concept of validation of design, construction, and installation, or of significant change on an installation, which is roughly analogous to the Norwegian requirements. These are currently enshrined in the PSLA (Management of Safety on Offshore Facilities) Regulations 1996. ${ }^{15}$

Originally, the PSLA Schedule of Requirements for Offshore Operations ${ }^{166}$ required an operator to obtain a certificate of verification of design for an installation from a competent verification body. This certificate required the verification body to be satisfied as to the construction and installation of the facility in several specific regards (for example, that a structural analysis had been made for critical loadings, that fatigue analysis of critical joints had been undertaken, and that an assessment of steel grades had been conducted with regard to certain specified parameters). This section of the PSLA Schedule of Requirements for Offshore Operations was repealed and replaced by Regulation 13 of the PSLA (Management of Safety on Offshore Facilities) Regulations 1996. The latter regulations are less prescriptive in nature than those previously applied and require that an operator validates, to the reasonable satisfaction of the designated authority, that in the case of both proposed and existing facilities its design, construction, and installation are "fit for purpose" and consistent with the Formal Safety Assessment relating to the facility required elsewhere in the regulations. The previously prescriptive requirements that applied in relation to the means by which this validation is to be achieved no longer appear. 
The most obvious difference between what is required in Australia and elsewhere with regard to verification, validation, or certification is that there is no requirement under Australian law for any ongoing activities in this regard - the regulations only apply at the design, construction, and installation stage for new projects and during major change on existing installations.

\section{B. InTERNATIONAL MARITIMf, ORGanization}

The International Maritime Organization (IMO) has recently taken positive steps toward the development of goal-based standards for new ship construction. ${ }^{17}$

The new ship construction standards are to be based on the premise that the standards should be "broad, over-arching goals against which ship safety should be verified at design and construction stages and during ship operation." 118 The primary objective is to develop standards which allow that "the safety of a ship could be assessed during its design and construction, as well as later on during its operation."

A working group has been formed that agreed in principle upon a five-tier approach to development:

- Tier I (goals)

- Tier II (functional requirements)

- Tier III (verification of compliance criteria)

- Tier IV (technical procedures and guidelines, classification rules, and industry standards)

- Tier V (codes of practice and safety and quality systems for shipbuilding, ship operation, maintenance, training, manning, elc. $)^{120}$

The intention currently is that Tiers IV and V will be developed by classification societies, other recognized organizations, and industry organizations. The working group also has on its agenda an intention to explore the linkage between Formal Safety Assessment (FSA) and goal-based standards, as well as to assess "how goal-based standards could be incorporated in the appropriate IMO instruments."121

The working group has already produced Tier I goals, which address safety and environmental issues "with respect to structural integrity and strength, dismantling and standards for new ships," 79th Sess., December 2004, online: IMO <www.imo.org/Newsroom/ mainframe.asp?topic_id=848\&doc_id=4574\#goal>. 
recycling and the need for design and construction to provide for safe access, inspection and proper maintenance."'22

\section{Environmental Compliance Models}

Environmental regulation in most jurisdictions is predominantly prescriptive. However, environmental legislation in Australia has undergone a process of modification over the years. ${ }^{123}$ Previously, environmental performance was addressed primarily through certain standing directions, as provided for by the PSLA. ${ }^{124}$ The standing directions made under the $P S L A$ were legislative in nature, requiring the offshore petroleum industry's compliance, but were not subject to parliamentary scrutiny. However, it is Australian government policy ${ }^{125}$ that all subordinate legislation be subject to parliamentary scrutiny and hence, these arrangements could not be continued indefinitely. The process of modification in Australia encompassed detailed discussion with stakeholder groups on the following three options:

- industry self-regulation,

- prescriptive regulation, and

- objective (performance-based) regulations. ${ }^{126}$

Self-regulation was rejected at an early stage of consultation on the grounds that neither industry nor public concerns would be adequately addressed under such a system. Prescriptive regulation was intended to provide a similar framework to that imposed by the existing standing instructions, except that the regulations would be subject to parliamentary scrutiny. Under a prescriptive approach, prescribed performance standards, management practices, and technology options would be set out in regulations covering all aspects of offshore operations. Industry would be required to follow strictly the prescriptive standards, practices, and technology options. Objective-based regulation was intended to establish a framework in which operators would be required to submit a proposal setting out how they proposed to undertake an activity. The primary objective would be to ensure that offshore operations were performed in a way that reduced environmental risks and effects to as low as reasonably practicable. This option also aimed to encourage continuous improvements in environmental performance and to permit industry to adopt environmental management practices and technologies best suited to individual company circumstances, activities, and locations. ${ }^{127}$

Ibid.

Austl., Commonwealth, National Oceans Office, “Australia's Occans Policy," online: National Oceans Ollies <www.oceans.gov.au/the_occans_policy_overview.jspp.

Supra nole 61.

Caring. Understanding, Using Wisely, supro note 60.

Austl. . Commonweath, Department of Industry, Tourism and Resources, "Regulation Impact Statement: Petroleum (Submerged Lands) (Diving Safety) Regulations 2002," online: ITR <wwwl.industry. gov.au/library/content_library/DivingRegulationsRegulatory/mpactStatement.pdP at 2.

ibid. al 3-5. 
Following consultation, the third of the above options was selected and the previously applying standing directions were replaced in 1999 by performance-based regulations for the management of environmental performance for Australian offshore activities in areas of Commonwealth jurisdiction. ${ }^{128}$

Objective-based regulations were thought to encourage the use of best practices and technologies as they become available, resulting in improved environmental outcomes.

In common with both the U.K. and Norway, a key feature of the regulations is the requirement that an operator submit an environment plan before commencing any petroleum activity. An accepted environment plan establishes legally binding environment management conditions that must be met by the operator of an offshore petroleum activity. ${ }^{129}$

Operators are required to submit a proposed revision of the environment plan to the designated authority before the commencement of any new activity, or any significant modification, change, or new stage of an existing activity, or upon a significant increase in or the occurrence of any significant new, environmental effect or risk not provided for in the current environment plan. The plan must also be revised every five years, regardless of whether or not it has been modified in the previous period. ${ }^{130}$

\section{Summary AND CONCI.usions}

In the U.K., a distinction is made between regulation of day-to-day occupational health and safety matters and risk management with a view to avoiding major catastrophes. Day-today OHS matters are governed by the $H S W A,{ }^{\mid 3 \prime}$ which is of general application to all industries. Risk management of major catastrophes is the subject of the safety case regime adopted in light of the Piper Alpha casualty both onshore and offshore. There are substantial similarities between the two. Both are based on performance, require risk assessment, and place the duty to ensure safety on the operator, leaving it to the operator to determine how best to perform this duty in the context of its own operations while avoiding detailed stipulation as to how safety is to be achieved. Further, both regimes are administered and. where necessary, enforced by the Health and Safety Exccutive. ${ }^{132}$ Norway, regulating essentially the same industry in the same North Sea environment as the U.K., over time adopted a similar system that imposes performance-based safety duties on the operator. without specifically requiring a U.K.-style safety case. ${ }^{133}$ Australia, following close analysis of the success of the U.K. safety case regime, largely adopted that model. Under current proposals for amendment to the safety regulatory regime in Australia, the safety case model will incorporate OHS requirements, as well as risk management against catastrophic

PSLA (Management of Safen on Offshore Facilitics) Regulutions 1996. supra note 65.

Austl.. Commonwealth. Department of Industry, Tourism and Resources. Resourecs Division. Giridelines for Preparation and Submission of an Environmem Plan (January 2(0)3), online: ITR <www.industry.gov.au/content/itrinterne $/$ cmscontent.cfm?objectID-364C134CE.-F5B2-48EC. 93C65B7F9326FC72> at para. 5.2.

lhid. at para. 9.1.

Supra note 16.

U.K., ISE-Orfshore, "How we work." online: HSE <www.hse.gov.uk/offshore/how. htm>.

Supra note 114. 
casualties. ${ }^{134}$ Implementation of a performance-based regulatory regime does not necessarily require the adoption of a U.K.-style safety case model, although the benefits associated with that model should not be overlooked. In the U.K., for example, day-to-day OHS regulation is achieved outside the ambit of the safety case requirements, although in practice many operators include OHS matters in their safety case submissions for the sake of completeness. ${ }^{135}$ Similarly, the NEB's currently proposed goal-oriented regulations are not predicated on adoption of a safety case regime. ${ }^{136}$

The most striking difference between Canada and the other regulatory regimes is the primary use elsewhere of a performance-based regulatory model in all matters affecting worker and installation safety. The underlying fundamental policy choices were rooted in differing responses to tragic offshore casualties. In Atlantic Canada, loss of the Ocean Ranger occurred in a very immature regulatory environment where the casualty was attributed in part to a lack of rules, and a lack of sufficient regulatory authority and expertise to detect and remedy safety deficiencies. ${ }^{137}$ The legislative and regulatory response, over time, was the promulgation of rules and the empowering and mandating of regulators to ensure adherence to the rules - in short, a largely prescriptive safety-regulatory regime. In contrast, the loss of the Piper Alpha occurred in a robust industry governed by a relatively well-established regulatory regime. ${ }^{138}$ In that context, the identification of stagnating effects of an excessively prescriptive regime, inhibiting innovation and proactive risk management in workplace safety, led to a greater emphasis on management systems and risk analysis in short, to the evolution of a safety case regulatory model. ${ }^{139}$

A fundamental component of the PBR regimes in the above jurisdictions is the concept that the regulatory authority gives its consent to the activity proposed to be undertaken by the operator, as opposed to its approval of the proponent's application. It is implicit in this concept that the regulator declines to accept responsibility for the adequacy of the operator's plan, responsibility for which remains at all times with the operator itself. In legal and regulatory theory, the authority consents to an operator undertaking its proposed activity, without implying any official judgment as to adequacy.

All jurisdictions have had unfortunate experience with fatal casualties in their offshore industries. There is no method by which lawmakers, regulators, or industry can provide an absolute assurance of human safety in what is unquestionably a hazardous industry conducted in a hostile environment. Against this backdrop of a degree of unavoidable risk, 2005 (No. I) (Cth.); Petroleum (Stubmerged Lands) (Occuparional Health and Safery) Amendment Regulations 2005 (No. 2) (Cth.); these amendments came into effect on I September 2005. U.K., HSE. "Planning to do business in the UK offshore oil and gas industry?: What you should know about health and safety," onlinu: HSE <www.hse.gov.uk/offshore/guidance/entrants.pdB.

NEB, Strategic Plan 2006-2009: online: NEB <www.neb-one.gc.ca/AboutUs/StrategicPlan 2006_2009_s.pdrs. For example, see Draft for Consultation, Goal Oriented Drilling and Production Regulutions - April 2005, online: NEB <www,neb-one.gc.ca/AtsRegulations/COGOA/Goal OrientedDPRDraftApril2005_e.pdis.

137. Ocean Ranger Commission Reports, supra note 102.

135 Supra note 66.

134. For safety case regulation, see supra notes 18,37 and 65 . 
policy makers in the foregoing jurisdictions have addressed the adoption of safety regulatory models.

From the point of view of effectiveness of regulation, primarily of workplace safety but also of environmental protection and industry and production efficiency, the performancebased regulatory model has worked well. The safety records of the target jurisdictions, at least in terms of recent major casualties, appear no worse than those offshore Canada. ${ }^{140}$ This is especially remarkable taking into account the significantly greater offshore activity in the U.K. and Norwegian sectors of the North Sea. ${ }^{141}$ In summary, it appears that with more than a decade's experience (at least in the U.K.), performance-based regulation has been effective in practice.

From an industry perspective, offshore oil and gas exploration is conducted by large and sophisticated international operators with immense human and capital resources. Two observations immediately flow from this fact. First, these operators have achieved admirable safety and operational records under performance-based regimes elsewhere in the world. They know how effective safety management is done. If Canada were to adopt a similar safety-regulatory model to that which exists in other jurisdictions, there is reasonable assurance that the major operators to which that model would apply would be in a position to, and will in fact, apply in the Canadian offshore the same skills and sophistication that they are accustomed to applying in the other jurisdictions, and with similarly satisfactory results. Second, and more generally, these large operators allocate their own exploration and development resources based primarily on business considerations. If the cost of activity in the Canadian offshore is greater than that in other jurisdictions, then Canada risks being relatively unattractive to those operators thus reducing investment prospects in its stillnascent offshore industry. Such costs can be either compliance costs themselves, or process costs associated with the making of regulatory submissions and the time required to obtain regulatory approvals. In this general sense, the competitive position of Canada's offshore in the attraction of international exploration and development capital is a policy factor to be taken into account by those in a position to influence the direction of Canada's regulatory regime.

Performance-based regulation does not necessarily lower industry's compliance or operational costs. In a transition phase, costs may increase, both because of the need to acquire new in-house skills and the need to examine critically and modify operational practices frequently. Further, the need for these examinations and modifications is ongoing, as are their associated costs. Offsetting these are two further considerations. First, Canada is in a position to take the benefit of the learning and compliance investments that have

See under "Statistics" at U.K., Health and Safety Executive, Information, online: HSE < www. hse.gov.uk/ortshore/information.htm>: Australian Furure Arrangements, supra note 25; and General Conclusion in Norway PSA. Trends in risk levels - summany report Phase 5 (2004), online: PSA <www.ptil.no/English/Helse+miljo+og+sikkerhed/Risikonivaa + paa+sokkelen/RNNS+Fase+5+\% 282004\%29+SammendragsrappordS_mns04_eng_konklusjoner.htm>. 
already been made by operators under other regimes. Although there are some locally unique environmental factors (icebergs, for example) for which experience elsewhere could not be effectively imported, it is suggested that there would be few, if any, systems and management skill development costs incrementally incurred by operators if a performance-based regime evolved in Canada. Canada is in a position to benefit from economies already achieved by the operators elsewhere. Second, the operational costs associated with a performance-based regime are not necessarily imposed on the operator. To the extent that, in substance, existing prescriptive requirements are demonstrated to be adequate and are industry's preferred compliance option, no operational change should be required. The essence of a performancebased regime is the availability of choice to the operator. Choice maximizes flexibility, response to technological change, and, ultimately, business economy. These characteristics are presumed to be desirable to industry and so, if present, would enhance the attractiveness of Canada to industry as a candidate for investment.

Performance-based regulating imposes challenges on the regulator, particularly at the transition phase. Field inspectors must learn or possess management and systems-design skills of sophistication equal to those of their industry counterparts who create the systems, the adequacy of which the inspectors are required to assess and audit. Persons possessing those skills are in demand both by regulators and by industry, and the most highly skilled people tend to be attracted to more generous compensation packages in industry. The relative scarcity and therefore cost of skilled individuals are compounded by the regulator's desire, and one could argue its practical need, to support the regulated industry by performing necessary assessments and issuing necessary decisions within acceptable time frames. Particularly in transition, the avoidance (or at least the management) of regulatory delay requires a relatively greater number of skilled people than may be ultimately required to maintain a mature and functioning performance-based regime. The regulator and policy maker by whom it is empowered must recognize the effective need to devote relatively large human resources to a performance-based regime, and to be prepared to expend the necessary funds to ensure that the implementation of that regime is done correctly and credibly on the first attempt. Given these considerations, Canada, perhaps uniquely, is in a position to initiate the transition to a performance-based regime at a time when the industry is still operating at a relatively low level, such that the regulatory workload is lower than it will become with time. Regulators can best manage transition problems and transition costs at the relatively carly stage of development of the subject industry in Canada.

Lastly, the effective functioning of performance-based regimes depends largely on trust between industry and its regulators. This is a multi-faceted concept. Trust connotes general satisfaction with the regulatory process and with the quality and consistency of regulatory decisions. Trust connotes credibility of all parties with each other - earned with difficulty and easily lost when a problem occurs. Trust connotes transparency of applicable policy and decision-making criteria and the regulator's visible consistency in the conduct of its business. Trust, however, cannot be legislated into existence. Although it would be incorrect to suggest that an atmosphere of trust must exist before the successful evolution to a performance-based model can be initiated, recognition by all participants of the need to work together constructively to support implementation of and transition to a performance-based regulatory regime will itself expedite and smooth the transition process. 